\title{
ANALISIS EMPIRIS INKLUSIFITAS KEUANGAN SYARIAH DI INDONESIA
}

Azwar

Balai Diklat Keuangan Makassar, Indonesia. Email : azwar.iskandar@gmail.com

\section{INFO ARTIKEL}

SEJARAH ARTIKEL Diterima Pertama

31 Maret 2017

Dinyatakan Dapat Dimuat 6 November 2017

KATA KUNCI:

inklusif, keuangan, syariah, kesejahteraan.

\section{ABSTRAK}

Penelitian ini bertujuan untuk mengukur dan menganalisis inklusifitas keuangan syariah pada 33 provinsi di Indonesia. Dengan menggunakan data sekunder berbasis tahunan dari publikasi Bank Indonesia dan Badan Pusat Statistik, penelitian ini mengestimasi inklusifitas keuangan syariah di Indonesia dengan metode Index for Syariah Financial Inclusion (ISFI) yang dikembangkan dari Sarma (2012) berdasarkan tiga dimensi pengukuran yaitu accessibility, availability dan usage of banking services. Penelitian ini secara empiris membuktikan bahwa indeks inklusifitas keuangan syariah di Indonesia secara umum tergolong rendah yaitu dengan average value sebesar 0,127. Pada tingkat provinsi, ditemukan bahwa Provinsi Bangka Belitung memiliki indeks inklusifitas tertinggi dibandingkan provinsi lainnya di Indonesia. Temuan ini bermakna bahwa kelompok masyarakat tidak sepenuhnya menggunakan jasa keuangan formal, khususnya, sebagai sumber keuangan dan pembiayaan utama, sehingga pengambil kebijakan perlu untuk meningkatkan availabilitas keuangan syariah dengan menambah dan memperluas layanan perbankan syariah di Indonesai khususnya pada kawasan timur Indonesia. Lebih lanjut, penelitian ini juga menganalisis hubungan antara inklusifitas keuangan syariah dan kesejahteraan masyarakat. Melalui metode Product Moment Coefficient of Correlation, penelitian ini menemukan adanya korelasi positif dan signifikan antara inklusiftas keuangan syariah dan kesejahteraan masyarakat di Indonesia. Umumnya, provinsi dengan Human Devepelment Index (HDI) yang tinggi dan medium dapat dianalogikan relatif memiliki inklusi keuangan yang tinggi pula.

This paper analyzes the index of syariah financial inclusion across the 33 provinces in Indonesia. As the inclusiveness of a financial system depends on various criteria, an Index for Syariah Financial Inclusion (ISFI) has been constructed using a multidimensional approach. Using the annual secondary data from Bank Indonesia and Badan Pusat Statistik for three dimensions i.e. accessibility, availability and usage of banking services, ISFI has been computed for various provinces of Indonesia in period of 2010-2015. It is found that index of syariah financial inclusive in Indonesia generally still low with average value of $\mathbf{0 . 1 2 7}$. The province of Bangka Belitung is the most financially inclusive province of Indonesia. Further, the relationship between financial inclusion and human development index as proxy of welfare has been investigated. The empirical results show that the index of syariah financial inclusion and human development index are positively correlated with each other. It is observed that although various measures have been implemented to increase financial inclusion, a large population of Indonesia does not have access to formal financial system yet. Thus, the promotion of syariah financial inclusion should be a policy priority in Indonesia to achieve the central goals of inclusive growth, welfare and economic development. 


\section{PENDAHULUAN}

1.1. Latar Belakang

Keberhasilan pembangunan ditandai dengan terciptanya suatu sistem keuangan yang stabil dan memberi manfaat bagi seluruh lapisan masyarakat. Dalam hal ini, institusi keuangan memainkan peran penting melalui fungsi

intermediasinya untuk mendorong pertumbuhan ekonomi, pemerataan pendapatan, pengentasan kemiskinan dan pencapaian stabilitas sistem keuangan. Hanya saja industri keuangan yang berkembang sangat pesat belum tentu disertai dengan akses keuangan yang memadai. Padahal, akses layanan jasa keuangan merupakan syarat penting keterlibatan masyarakat luas dalam sistem perekonomian.

Indonesia termasuk negara dengan tingkat financial exclusion yang cukup tinggi. Hal ini terlihat dari beberapa hasil survei dan penelitian yang dilakukan oleh beberapa lembaga nasional maupun internasional. Survei Neraca Rumah Tangga (2011) oleh Bank Indonesia menunjukkan bahwa persentase rumah tangga yang menabung di lembaga keuangan formal dan non-lembaga keuangan sebesar 48 persen. Dengan demikian masyarakat yang tidak memiliki tabungan sama sekali baik di bank maupun di lembaga keuangan non-bank masih relatif sangat tinggi yaitu sekitar $52 \%$. Sementara Survei Bank Dunia (2010) menunjukkan hanya 49 persen rumah tangga Indonesia yang memiliki akses terhadap lembaga keuangan formal. Kedua survei tersebut saling menguatkan fakta bahwa akses keuangan masyarakat Indonesia ke lembaga keuangan formal dan non-formal masih relatif rendah sehingga penduduk Indonesia yang memiliki akses yang terbatas terhadap sistem jasa keuangan masih perlu ditingkatkan.

Meskipun demikian, dengan segala permasalahan tersebut di atas, akses masyarakat kepada layanan keuangan di Indonesia sebenarnya tergolong moderat dibandingkan negara berkembang lainnya. Tingkat akses penduduk Indonesia pada layanan keuangan lebih besar dari dua emerging giants, India dan Cina, dan hanya sedikit di bawah Thailand, Malaysia, dan Korea Selatan. Artinya, masih ada ruang untuk membuat sistem keuangan Indonesia lebih inklusif dan meraih keuntungan sosial yang lebih besar (Bank Indonesia, 2014). Mengingat pentingnya isu ini, pembahasan keuangan inklusif menjadi salah satu agenda penting dalam dunia internasional. Forum internasional seperti G20, Asia-Pacific Economic Cooperation (APEC), Alliance for Financial Inclusion (AFI), Organisation for Economic Cooperation and Development (OECD) dan ASEAN secara intensif melakukan pembahasan mengenai keuangan inklusif. Selain itu, keuangan inklusif juga telah masuk dalam prioritas pemerintah Indonesia. Pada bulan Juni 2012, Bank Indonesia bekerjasama dengan Tim

Nasional Percepatan Penanggulangan Kemiskinan (TNP2K) dan Badan Kebijakan Fiskal Kementerian Keuangan mengeluarkan Strategi Nasional Keuangan Inklusif. Strategi ini berisi kerangka kerja, implementasi dan langkah ke depan pelaksanaan keuangan inklusif. Strategi nasional ini diharapkan menjadi jalan

terciptanya kolaborasi antarlembaga pemerintah dan pemangku kepentingan secara baik dan terstruktur.

Peran perbankan nasional sebagai lembaga intermediasi keuangan bagi masyarakat memegang peranan yang vital dalam mewujudkan program nasional ini. Keuangan inklusif sangat relevan untuk mendukung efektivitas fungsi dan tugas Bank Indonesia dan perbankan nasional baik dari sisi moneter, sistem pembayaran maupun makroprudensial. Perbankan syariah sebagai bagian dalam industri perbankan nasional, dengan karakteristiknya yang khusus juga memiliki potensi yang besar untuk memberikan kontribusi dalam mewujudkan inklusifitas keuangan nasional. Perbankan dan industri keuangan syariah secara umum ditantang untuk memberikan perannya. Apalagi hal ini dikuatkan dengan hasil survei oleh Otoritas Jasa Keuangan (OJK) pada tahun 2016 yang menemukan bahwa meskipun mayoritas penduduk Indonesia merupakan umat muslim, namun pada kenyataannya tingkat literasi dan inklusi keuangan syariah masih jauh dari maksimal. Berdasarkan survei tersebut ditemukan bahwa dari 100 orang penduduk muslim, hanya 8 orang yang memahami produk dan layanan keuangan syariah dan 11 orang yang memiliki akses terhadap produk dan layanan 
lembaga jasa keuangan syariah. 1 . Rasio ini tentu saja menjadi catatan penting bagi upaya peningkatan peran perbankan dan industri keuangan syariah saat ini.

Deputi Gubernur Bank Indonesia, Halim

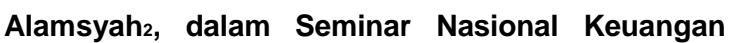
Inklusif tahun 2016 mengemukakan bahwa keuangan syariah dan kebijakan keuangan inklusif memiliki potensi untuk bersinergi dengan baik, mengingat kesamaan konsep yaitu keuangan inklusif bertujuan memberikan akses keuangan yang mudah, murah, aman dan sesuai bagi masyarakat unbanked, serta bertujuan untuk meningkatkan kapabilitas masyarakat agar mampu hidup lebih sejahtera dan keluar dari garis kemiskinan. Sementara prinsip syariah bertujuan untuk menyejahterakan masyarakat melalui prinsip partnership dan profit sharing. Selain itu, saat ini berkembang juga beberapa pemikiran tentang Islamic Financial Inclusion khususnya terkait dengan pemanfaatan potensi dari kegiatan yang bernilai sosial. Sektor sosial Islam yang mencakup sistem zakat dan wakaf dengan potensi sekitar Rp 217 triliun (atau setara dengan 3,4 persen Produk Domestik Bruto Indonesia) dapat memainkan peran yang sangat penting untuk mempercepat pembangunan ekonomi dan mendukung stabilitas keuangan.

Lebih lanjut, Deputi Komisioner Pengawas Perbankan OJK, Mulya E. Siregar, mengatakan bahwa di tahun-tahun akan datang, OJK memiliki beberapa sasaran arah pengembangan industri keuangan syariah, yaitu membuka akses masyarakat kurang mampu dalam rangka mendukung inklusi keuangan, menangkap potensi bertumbuhnya kelas menengah melalui penyediaan produk dan jasa keuangan yang variatif dan inovatif sesuai kebutuhan, dan harus berkontribusi pada pembiayaan jangka panjang dan sektor prioritas pemerintah untuk mencapai target pertumbuhan ekonomi.

Oleh karena itu, mengingat peranan inklusifitas sektor keuangan menjadi sangat penting bagi pertumbuhan ekonomi, kajian terkait inklusifitas keuangan syariah di Indonesia seyogyanya menjadi agenda yang sangat penting dan menarik untuk dilakukan baik oleh para peneliti dan pemegang kebijakan

\footnotetext{
${ }^{1}$ http://infobanknews.com/tingkat-literasi-dan-inklusikeuangan-syariah-masih-minim/2/

2 http://mysharing.co/keuangan-syariah-dankeuangan-inklusif-bisa-bersinergi/
}

terkait. Selain itu, kajian ilmiah yang berfokus pada pengukuran dan determinan inklusi keuangan syariah di Indonesia dirasakan masih sangat minim dan menjadi salah satu poin yang dapat menyebabkan upaya pemerintah dalam case ini menjadi kurang optimal karena pemahaman dan wawasan tentang dinamikanya relatif terbatas.

Untuk menjembatani gap tersebut di atas, penelitian ini mencoba menganalisis dan mengukur inklusifitas sektor keuangan syariah di Indonesia. Penelitian ini menjadi berbeda dan terbaru dari penelitian-penelitian inklusifitas sektor keuangan sebelumnya seperti yang dilakukan oleh Sarma (2012), Gupta et al. (2014) dan Sanjaya dan Nursechafia (2016) yang masih melihat dan mengkaji inklusifitas keuangan dalam konteks non-syariah (konvensional). Sementara, penelitian ini menggunakan cakupan yang lebih khusus yaitu pada sektor perbankan atau keuangan syariah. Bahkan, sejauh yang penulis ketahui, penelitian ini merupakan yang pertama yang mengukur dan menganalisis inklusifitas sektor keuangan syariah di Indonesia. Selanjutnya, untuk mencari tahu bagaimana hubungan inklusifitas keuangan syariah dan kesejahteraan masyarakat maka dibutuhkan studi tersendiri. Hasil penelitian ini diharapkan dapat memberikan masukan bagi pemerintah dan pihak terkait dalam merancang kebijakan ekonomi dan keuangan inklusif yang berbasis pada bukti dan temuan empiris.

\subsection{Permasalahan Penelitian}

Berdasarkan uraian latar belakang di atas, masalah penelitian ini dirumuskan sebagai berikut :

1. Bagaimana inklusifitas keuangan syariah pada 33 provinsi di Indonesia?

2. Bagaimana hubungan antara inklusifitas keuangan syariah dan kesejahteraan masyarakat di Indonesia?

\subsection{Tujuan Penelitian}

Sesuai dengan rumusan permasalahan yang hendak dijawab dalam penelitian ini, maka penelitian ini bertujuan untuk :

1. Mengukur dan menganalisis inklusifitas

\footnotetext{
${ }^{3}$ http://mysharing.co/ini-arah-pengembangankeuangan-syariah-jelang-mea/
} 
keuangan syariah pada 33 provinsi di Indonesia;

2. Menganalisis hubungan antara inklusifitas keuangan syariah dan kesejahteraan masyarakat di Indonesia.

\section{KERANGKA TEORITIS}

Pada bagian ini peneliti menyajikan berbagai tinjauan pustaka yang berhubungan dengan teori atau konsep terkait topik penelitian dan bukti empiris dari penelitian-penelitian sebelumnya.

\subsection{Inklusi Keuangan}

Istilah financial inclusion atau keuangan inklusif menjadi tren paska krisis 2008 terutama didasari oleh dampak krisis kepada kelompok the bottom of the pyramid (pendapatan rendah dan tidak teratur, tinggal di daerah terpencil, orang cacat, buruh yang tidak mempunyai dokumen identitas legal, dan masyarakat pinggiran) yang umumnya termasuk kategori unbanked yang tercatat sangat tinggi di luar negara maju. Pada G20 Pittsbugh Summit 2009, anggota G20 sepakat akan perlunya peningkatan akses keuangan bagi kelompok ini yang dipertegas pada Toronto Summit tahun 2010, dengan dikeluarkannya 9 Principles for Innovative Financial Inclusion sebagai pedoman pengembangan keuangan inklusif. Prinsip tersebut adalah leadership, diversity, innovation,

protection, empowerment, cooperation, knowledge, proportionality, dan framework (Bank Indonesia, 2014).

Berbagai alasan menyebabkan masyarakat dimaksud menjadi unbanked, baik dari sisi supply (penyedia jasa) maupun demand (masyarakat), yaitu karena price barrier (mahal), information barrier (tidak mengetahui), design product barrier (produk yang cocok) dan channel barrier (sarana yang sesuai). Keuangan inklusif mampu menjawab alasan tersebut dengan memberikan banyak manfaat yang dapat dinikmati oleh masyarakat, regulator, pemerintah dan pihak swasta, antara lain sebagai berikut:

Meningkatkan efisiensi ekonomi.

Mendukung stabilitas sistem

keuangan. Mengurangi shadow

banking atau irresponsible finance.

Mendukung pendalaman pasar

keuangan.
Memberikan potensi pasar baru

bagi perbankan.

Mendukung peningkatan Human

Development Index (HDI) Indonesia.

Berkontribusi positif terhadap pertumbuhan ekonomi lokal dan nasional yang sustain dan berkelanjutan.

Mengurangi kesenjangan (inequality) dan rigiditas low income trap, sehingga dapat meningkatkan kesejahteraan masyarakat yang pada akhirnya berujung pada penurunan tingkat kemiskinan.

Sejak saat itu banyak forum-forum internasional yang memfokuskan kegiatannya pada keuangan inklusif seperti Consultative Group to Assist the Poor (CGAP), World Bank, APEC, Asian Development Bank (ADB), AFI, Financial Action Task Force (FATF), termasuk negara berkembang dan Indonesia (Bank Indonesia, 2014).

Beberapa penelitian telah banyak meyakinkan para ekonom dan pengambil kebijakan di negara berkembang tentang dampak positif dari sektor keuangan inklusif terhadap pertumbuhan ekonomi dan pengurangan kemiskinan. Namun demikian, masih belum ada definisi global dan baku dari keuangan inklusif yang menjelaskan apa sebenarnya inklusi keuangan itu sendiri. Berbagai studi dan institusi mencoba untuk mendefinisikannya, sebagai berikut:

Leyshon dan Thrift (1995) menjelaskan bahwa inklusi keuangan merupakan antitesis dari eksklusi keuangan. Proses eksklusi keuangan membuat masyarakat miskin tidak dapat mengakses benefit dari sektor keuangan dan memberikan kerugian kepada masyarakat untuk mendapatkan akses terhadap sistem keuangan dikarenakan kurangnya akses, jaminan, riwayat kredit, dan jaringan.

Global Partnership for Financial Inclusion (GPFI-CGAP) Forum pada tahun 2012 mendefinisikan inklusi keuangan sebagai: "state in which all working age adults have effective access to credit, savings, payments, and insurance from formal service providers. Effective access involves convenient and responsible service delivery, at a cost affordable to the customer and sustainable for the provider, with the result that financially excluded customers use formal 
financial services rather than existing informal options".

Menurut FATF, "financial inclusion involves providing access to an adequate range of safe, convenient and affordable financial services to disadvantaged and other vulnerable groups, including low income, rural and undocumented persons, who have been underserved or excluded from the formal financial sector".

Reserve Bank of India (RBI) mendefinisikan inklusi keuangan sebagai: "process of ensuring access to appropriate financial products and services needed by all sections of the society in general and vulnerable groups such as weaker sections and low income groups in particular, at an affordable cost in a fair and transparent manner by regulated, mainstream institutional players".

Sementara, dalam Strategi Nasional Keuangan Inklusif, keuangan inklusif digambarkan sebagai kondisi dimana: "hak setiap orang untuk memiliki akses dan layanan penuh dari lembaga keuangan secara tepat waktu, nyaman, informatif, dan terjangkau biayanya, dengan penghormatan penuh kepada harkat dan martabatnya. Layanan keuangan tersedia bagi seluruh segmen masyarakat, dengan perhatian khusus kepada orang miskin, orang miskin produktif, pekerja migrant, dan penduduk di daerah terpencil" (Bank Indonesia, 2014).

Sejak tahun 2000-an, inklusi keuangan telah secara luas digunakan sebagai fokus utama kebijakan di banyak pemerintahan dan bank sentral untuk membangun negaranya. Di India, inklusi keuangan menekankan pada proses untuk memastikan bahwa akses terhadap sistem jasa keuangan and kredit yang memadai bagi masyarakat miskin dengan biaya yang terjangkau (Rangrajan Committee, 2008). Di Peru, Reyes (2010) mengungkapkan pentingnya perluasan akses bagi sebagai besar masyarakat terhadap portofolio produk dan jasa keuangan, seperti pinjaman, deposito, asuransi, pensiun, sistem pembayaran, serta mekanisme pendidikan keuangan dan perlindungan konsumen.

Di Indonesia, inklusi keuangan menjadi strategi nasional untuk mendorong pertumbuhan ekonomi melalui distribusi pendapatan yang merata, penurunan tingkat kemiskinan, dan stabilitas sistem keuangan
(Hadad, 2010). Hak setiap individu dijamin untuk dapat mengakses seluruh cakupan kualitas jasa keuangan dengan biaya yang terjangkau. Target dari kebijakan ini sangat memperhatikan masyarakat miskin berpendapatan rendah, masyarakt miskin produktif, pekerja migran, dan masyarakat yang hidup di pelosok (Bank Indonesia, 2014). Sederhananya, beberapa penelitian yang ada saat ini telah menghubungkan paling tidak tiga poin inklusi keuangan yaitu akses, kelompok masyarakat, dan sistem keuangan (Demirgüç-Kunt et al., 2008; Sarma dan Pais, 2008; Sarma, 2008; Demirgüç-Kunt dan Klapper, 2012).

Dari berbagai belahan dunia, untuk meningkatkan financial inclusion dan menurunkan financial exclusion, dilakukan dalam dua pendekatan, yaitu secara komprehensif dengan menyusun suatu strategi nasional seperti Indonesia, Nigeria, Tanzania dan melalui berbagai program terpisah, misalnya edukasi keuangan seperti yang dilakukan oleh pemerintah Amerika Serikat paska krisis 2008. Secara umum, pendekatan melalui suatu strategi nasional mencakup 3 (tiga) aspek, yaitu penyediaan sarana layanan yang sesuai, penyediaan produk yang cocok, responsible finance melalui edukasi keuangan dan perlindungan konsumen. Penerapan keuangan inklusif umumnya bertahap dimulai dengan target yang jelas seperti melalui penerima bantuan program sosial pemerintah atau pekerja migran sebelum secara perlahan dapat digunakan oleh masyarakat umum.

Strategi keuangan inklusif di Indonesia bukanlah sebuah inisiatif yang terisolasi, sehingga keterlibatan dalam keuangan inklusif tidak hanya terkait dengan tugas Bank Indonesia, namun juga regulator, kementerian dan lembaga lainnya dalam upaya pelayanan keuangan kepada masyarakat luas. Melalui strategi nasional keuangan inklusif diharapkan kolaborasi antar lembaga pemerintah dan pemangku kepentingan tercipta secara baik dan terstruktur.

\subsection{Indikator Inklusi Keuangan}

Bank Indonesia menetapkan Indeks Keuangan Inklusif (IKI) sebagai salah satu cara alternatif untuk pengukuran keuangan inklusif yang menggunakan indeks 
multidimensional berdasarkan data makroekonomi, terutama pada jangkauan layanan sektor perbankan. Pengukuran IKI pada dasarnya merupakan upaya yang dilakukan Bank Indonesia untuk mengkombinasikan berbagai indikator sektor perbankan, sehingga pada akhirnya IKI dapat menggabungkan beberapa informasi mengenai berbagai dimensi dari sebuah sistem keuangan yang inklusif, yaitu akses (access), penggunaan (usage) dan kualitas (quality) dari layanan perbankan.

Dimensi akses adalah dimensi yang digunakan untuk mengukur kemampuan penggunaan jasa keuangan formal, sehingga dapat dilihat terjadinya potensi hambatan untuk membuka dan mempergunakan rekening bank, seperti biaya atau keterjangkauan fisik layanan jasa keuangan (kantor bank, ATM, dII.). Indikator yang dipergunakan dalam mengukur dimensi akses meliputi: (1) jumlah kantor bank per 100.000 penduduk dewasa; (2) jumlah ATM per 10.000 penduduk dewasa; (3) jumlah kantor bank per 1.000 km2; dan (4) jumlah ATM per 1.000 km2.

Dimensi penggunaan adalah dimensi yang digunakan untuk mengukur kemampuan penggunaan aktual produk dan jasa keuangan, antara lain terkait keteraturan, frekuensi dan lama penggunaan. Indikator yang dipergunakan dalam mengukur dimensi akses meliputi: (1) jumlah rekening Dana Pihak Ketiga (DPK) yang terdiri dari deposito, giro dan tabungan per 1.000 penduduk dewasa; dan (2) jumlah rekening kredit per 1.000 penduduk dewasa.

Sedangkan dimensi kualitas adalah dimensi yang digunakan untuk mengetahui apakah ketersediaan atribut produk dan jasa keuangan telah memenuhi kebutuhan pelanggan. Pengukuran terhadap dimensi ini masih sukar untuk dilakukan dan saat ini beberapa lembaga internasional yang concern dalam pengembangan keuangan inklusif sedang menyusun indikator dari dimensi kualitas beserta tools yang dipergunakan. Secara umum The Alliance for Financial Inclusion (AFI) telah menyepakati prinsip-prinsip yang dipergunakan dalam menyusun indikator dari dimensi kualitas, meliputi ringkas (conciseness), spesifik (specifity), sederhana (simplicity), adanya perbaikan (improvement), dan client perspective.
Sementara dalam literatur lainnya, seperti pada Sarma (2012), Gupta et. al. (2014), Sanjaya dan Nursechafia (2016), menggunakan indikator atau dimensi pengukuran pada metode perhitungan Index Financial Inclusion (IFI) berupa aksesibilitas (penetration), availabilitas (availability) dan penggunaan jasa perbankan (usage of banking services). Dimensi penetrasi diwakili oleh jumlah rekening deposit per 1.000 jumlah orang dewasa, dimensi availibilitas diwakili oleh jumlah bank outlets per 1000 jumlah penduduk dan/atau jumlah ATM per 1000 jumlah penduduk, dan dimensi penggunaan diwakili oleh rasio volume dari two basic services of the banking system yaitu credit dan deposit dari jumlah penduduk dewasa terhadap nilai Gross Domestic Product (GDP). IFI yang rendah ditunjukkan dengan rendahnya pendapatan masyarakat kelas menengah, sedangkan kebanyakan negara berpendapatan tinggi memiliki IFI yang tinggi.

\subsection{Inklusi Keuangan dan Kesejahteraan Studi empiris menunjukkan hubungan} positif antara perkembangan sistem keuangan dan pertumbuhan ekonomi dalam jangka panjang (Levine, 2005). Pada regresi dengan menggunakan sampel antarnegara (crosscountry regression), Demirguc-Kent, Beck dan Honohan (2008) mengukur dampak perkembangan intermediasi keuangan terhadap masyarakat miskin dan kesenjangan pendapatan. Hasilnya menunjukkan bahwa pertumbuhan sektor keuangan memberikan dampak positif terhadap (i) menurunnya kesenjangan pendapatan (koefisien Gini), (ii) peningkatan pendapatan masyarakat yang sangat miskin, dan (iii) menurunnya persentase populasi masyarakat yang hidup di bawah garis kemiskinan. Demirguc-Kunt, Beck dan Honohan (2008) mengungkapkan bahwa akses keuangan pro-poor menurunkan kesenjangan pendapatan dan kemiskinan dengan lebih cepat.

Di Indonesia, inklusi keuangan menjadi strategi nasional untuk mendorong pertumbuhan ekonomi melalui distribusi pendapatan yang merata, penurunan tingkat kemiskinan, dan stabilitas sistem keuangan (Hadad dalam Sanjaya dan Nursechafia, 2016). Hak setiap individu dijamin untuk dapat mengakses seluruh cakupan kualitas jasa 
keuangan dengan biaya yang terjangkau. Target dari kebijakan ini sangat memperhatikan masyarakat miskin berpendapatan rendah, masyarakt miskin produktif, pekerja migran, dan masyarakat yang hidup di pelosok (Bank Indonesia, 2014).

Pembangunan sektor keuangan, terutama sektor perbankan, dapat meningkatkan akses dan penggunaan jasa perbankan oleh masyarakat. Semakin terbukanya akses terhadap jasa keuangan, masyarakat diharapkan dapat

memanfaatkan akses tersebut serta meningkatkan pendapatannya melalui penyaluran kredit oleh lembaga keuangan terutama apabila digunakan untuk kegiatan produktif. Sulitnya akses terhadap jasa keuangan menyebabkan masyarakat miskin harus mengandalkan tabungan yang terbatas untuk investasi dan pengusaha kecil harus mengandalkan laba untuk meneruskan usaha. Akibatnya, ketimpangan pendapatan tidak berkurang dan pertumbuhan ekonomi melambat (Allen et al., 2012).

Terdapat program transisi untuk memberdayakan masyarakat miskin dengan menggunakan kredit mikro untuk pembiayaan mikro. Pada prosesnya, inklusifitas keuangan menawarkan sejumlah jasa keuangan yang lebih luas termasuk kredit, simpanan, transfer uang, dan asuransi (Robinson, 2001, Armendariz dan Murdoch, 2010). Dengan tujuan pemberdayaan masyarakat miskin untuk kehidupan yang lebih baik, konsep inklusi keuangan menjadi sangat penting untuk diimplementasikan.

Inklusi keuangan harus didukung dengan analisis empiris tentang bagaimana mengukur inklusi keuangan pada indikator ekonomi agregat. Lebih jauh lagi, hal ini dapat meningkatkan partisipasi masyarakat miskin pada pertumbuhan ekonomi dan akhirnya menciptakan pertumbuhan yang inklusif. Untuk menerapkannya, maka database Indonesia tentang inklusi keuangan dapat membantu mengembangkan kapasitas statistik lokal. Di samping itu, perbandingan antara indikator inklusi keuangan dan ditingkatkan antar ekonomi dan antar waktu (Sanjaya dan Nursechafia, 2016).

\subsection{Penelitian Terdahulu \\ Berkenaan dengan inklusi keuangan dan}

faktor-faktor yang memengaruhinya, beberapa penelitian mencoba untuk mengukur sejauh mana inklusi keuangan yang terdapat pada beberapa negara.

Honohan (2008) menggunakan pendekatan ekonometrika dari gabungan data survery based dan secondary data untuk mengestimasi proporsi rumah tangga yang dapat mengakses pelayanan atau jasa keuangan formal di $\mathbf{1 6 0}$ negara di dunia. Honohan menemukan bahwa indeks akses keuangan mempengaruhi secara siginifkan untuk menurunkan ketimpangan pendapatan.

Wachira dan Kihiu (2012) telah melakukan studi tentang pengaruh literasi keuangan terhadap akses jasa keuangan di Kenya pada tahun 2009, ternyata akses terhadap jasa keuangan tidak hanya dipengaruhi oleh tingkat literasi keuangan tetapi lebih besar dipengaruhi oleh tingkat pendapatan, jarak dari bank, usia, status perkawinan, jenis kelamin, ukuran rumah tangga, dan tingkat pendidikan.

Adapun studi Beck et al. (2007) di 99 negara pada tahun 2003-2004 menunjukkan bahwa faktor yang menentukan jangkauan sektor keuangan sama dengan faktor yang menentukan kedalaman sektor keuangan. Faktor-faktor tersebut adalah tingkat dari pembangunan yang diproksikan dengan GDP per kapita, kualitas institusi yang diproksikan dengan governance index, serta infromasi kredit yang diproksikan dengan credit information index.

Van der Werff et al. (2012), dalam studinya di 31 negara OECD tahun 2011, menunjukkan bahwa faktor yang mempengaruhi proporsi populasi yang mengakses perbankan adalah ketimpangan pendapatan, jumlah ATM dan bank per 100.000 populasi, tingkat kepercayaan masyarakat terhadap institusi yang diproksikan dengan corruption index dan GNI per kapita. Inklusi keuangan juga dipengaruhi oleh perkembangan teknologi.

Ummah (2013), dengan menggunakan perhitungan Index of Financial Inclusion yang dikembangkan oleh Sarma (2008) penelitiannya menemukan bahwa delapan negara di Asia yang diteliti dari tahun 2004-2011, Jepang dan Korea Selatan merupakan negara yang memiliki indeks inklusi keuangan tertinggi yaitu 0.9 dan 0.5, sedangkan Pakistan berada di posisi terendah dengan indeks rata-rata sebesar 0.1 . Regresi Tobit digunakan untuk melihat faktor 
pembangunan yang memengaruhi inklusi keuangan. Hasil yang diperoleh adalah tingkat pendapatan per kapita dan jumlah populasi di desa memengaruhi inklusi keuangan. Sedangkan pengangguran tidak signifikan memengaruhi inklusi keuangan.

Demirguc-Kent dan Klapper (2012), dalam penelitiannya yang mengukur penggunaan produk keuangan usia dewasa (level mikro) pada 148 negara pada tahun 2011 menemukan bahwa $50 \%$ orang dewasa di seluruh dunia (sampel) menggunakan jasa keuangan formal, dan lebih dari 2,5 milyar orang dewasa di seluruh dunia tidak memiliki akun jasa keuangan formal. Namun demikian, informasi parsial dan tidak lengkap dari analisis tingkat mikro dapat menyebabkan adanya mis-interpretasi tentang sejauh mana inklusi keuangan pada perspektif makro.
Sarma (2012) mengembangkan metode perhitungan Index Financial Inclusion (IFI) yang dapat digunakan untuk membandingkan tingkat inklusi keuangan antar negara atau provinsi dalam sebuah negara pada periode waktu tertentu. Metode ini memenuhi asumsi komparabilitas, properti matematika, dan tiga dimensi (aksesibilitas, availabilitas, dan penggunaan jasa perbankan). IFI yang rendah ditunjukkan dengan rendahnya pendapatan masyarakat kelas menengah, sedangkan kebanyakan negara berpendapatan tinggi memiliki IFI yang tinggi.

Gupta et. al. (2014) mengukur Index for Financial Inclusion (IFI) pada 28 negara bagian dan 6 regions di India menggunakan dimensi : penetration, availability dan usage of banking services, menemukan secara empiris bahwa indeks inkulis keuangan dan indek pembangunan manusia sebagai proksi

Tabel 1

Definisi Operasional Variabel

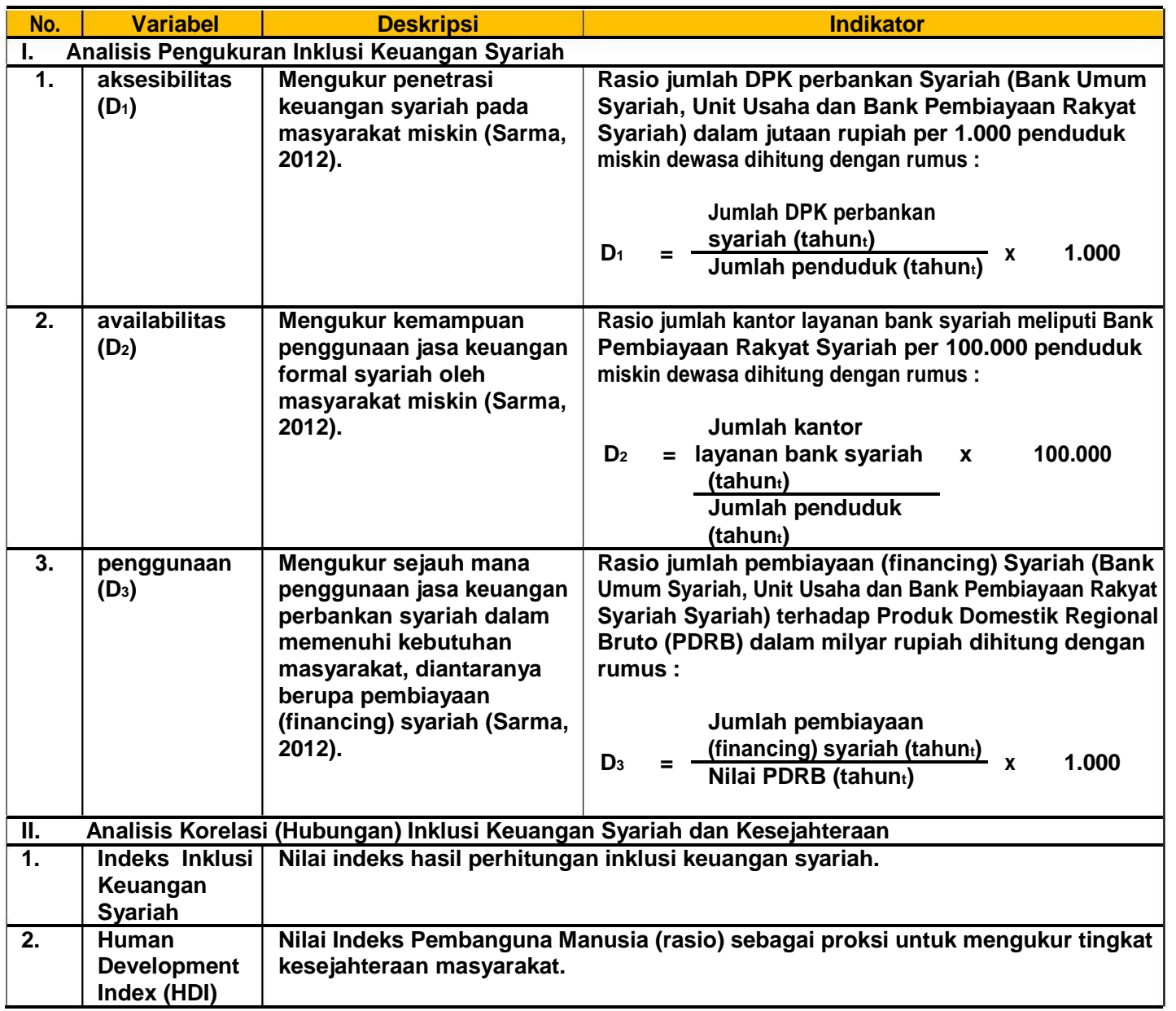


kesejahteraan masyarakat di India memiliki hubungan (korelasi) yang positif. Oleh karena itu, mereka menekankan prioritas kebijakan pemerintah India untuk mencapai pertumbuhan inklusif, pembangunan manusia dan ekonomi. Sanjaya dan Nursechafia (2016) dalam penelitiannya mengukur dan menganalisis tingkat inklusi keuangan dan pertumbuhan inklusif di Indonesia menemukan bahwa inklusi keuangan di Indonesia sangat dipengaruhi oleh dimensi aksesibilitas, sedangkan dimensi availabilitas dan penggunaan hanya memiliki proporsi yang kecil. Hal ini membawa kita pada kesimpulan bahwa kelompok masyarakat miskin cukup terbatas dalam memanfaatkan layanan jasa sektor keuangan.

\section{METODOLOGI PENELITIAN}

3.1. Data dan Variabel Penelitian Penelitian ini menggunakan data sekunder

berbasis tahunan yaitu tahun 2010-2015 pada 33 provinsi di Indonesia yang bersumber dari publikasi Badan Pusat Statistik (BPS) dan Bank Indonesia.

Mengingat bahwa penelitian ini menggunakan metode Indeks Inklusi Keuangan atau Index of Financial Inclusion (IFI) yang dikembangkan oleh Sarma (2012) dalam menganalisis dan mengukur inklusi keuangan syariah di Indonesia, maka variabel penelitian yang digunakan mengacu pada dimensi pengukuran IFI yaitu aksesibilitas $\left(d_{1}\right)$, availabilitas $\left(d_{2}\right)$, dan penggunaan $\left(d_{3}\right)$. Adapun terkait dengan analisis determinan terhadap inklusi keuangan serta dampak terhadap kesejahteraan, penelitian ini menggunakan beberapa faktor atau variabel yang dipilih yaitu jumlah penduduk miskin, jumlah kantor cabang bank, dan pendapatan daerah (PDRB). Definisi operasional seluruh variabel tersebut dapat dilihat pada Tabel 1.

\subsection{Metode Analisis}

Kajian ini menggunakan metode penelitian kuantitatif. Model dan teknik analisis yang digunakan dibedakan berdasarkan pertanyaan

penelitian sebagai berikut:

1. Untuk menjawab pertanyaan pertama, penelitian ini menggunakan model analisis Pengukuran Index of Financial Inclusion (IFI) yang digunakan oleh Sarma (2012). Metode ini digunakan karena menyajikan pengukuran komprehensif yang robust dan dapat dibandingkan antarprovinsi.

Secara detail, langkah dari metode ini dijabarkan sebagai berikut:

Pertama, kita menentukan nilai indeks inklusi setiap dimensi ( $\left.d_{i}\right)$ menggunakan rumus berikut:

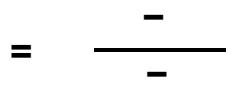

di mana:

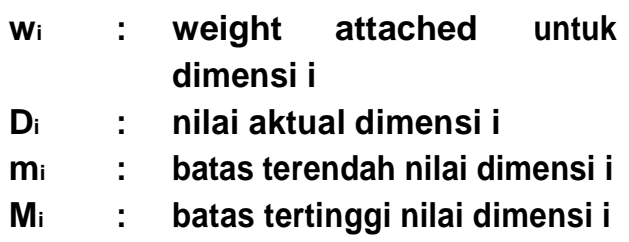

Pada penelitian ini, bobot yang digunakan (weight attached) untuk seluruh dimensi bernilai sama $\left(w_{i}=1\right)$. Dengan merujuk ke metode yang digunakan oleh Sarma (2012), penelitian ini mengasumsikan bahwa seluruh dimensi memiliki prioritas yang sama, sehingga bobot nilai nya adalah $\mathrm{w}_{\mathrm{i}}$

= 1 untuk seluruh i. Nilai dimensi yang mendekati wi menunjukkan area dengan capaian tertinggi pada seluruh dimensi.

Sarma (2012) secara empiris melakukan pengamatan batas minimum terendah dan batas maksimum tertinggi. Tidak seperti dimensi pembangunan manusia (human development), hal ini agak sulit untuk mengukur batas bawah dan batas atas inklusi keuangan. Namun demikian dikarenakan tidak adanya hasil outlier dalam kasus Indonesia, titik $M_{i}$ mewakili nilai maksimum dari data yang tersedia yang merupakan batas maksimum untuk setiap dimensi, sedangkan $m_{i}$ merepresentasikan batas terendah.

Kedua, menentukan nilai $\mathbf{X}_{1}$ dan $\mathbf{X}_{2}$ dengan menggunakan rumus di bawah ini:

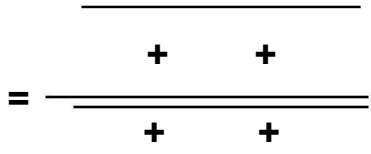




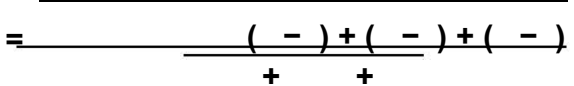

Ketiga, menentukan nilai IFI sebagai nilai rata-rata sederhana dari $X_{1}$ dan $X_{2}$ dengan rumus berikut:

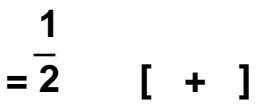

Gambar 1 berikut menunjukkan bagaimana inklusi keuangan terjadi :

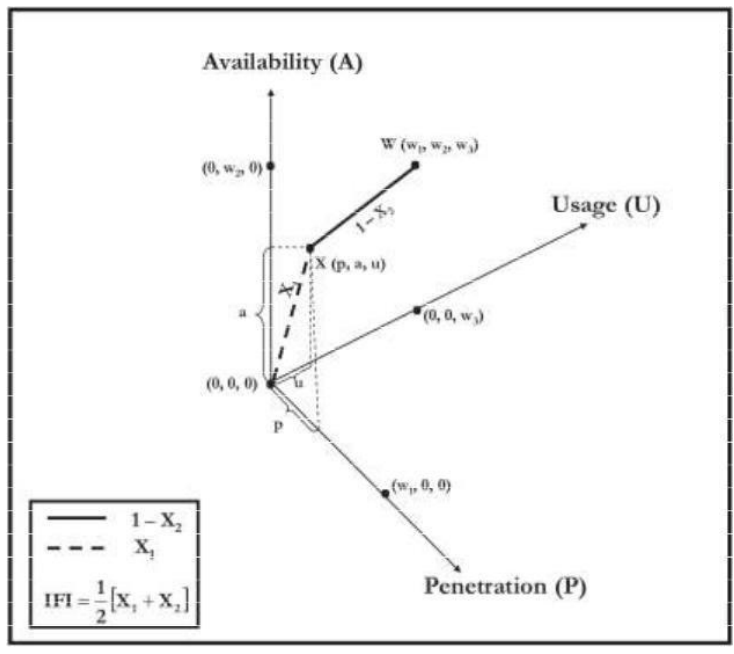

Gambar 1. Vektor Inklusi Keuangan

Sumber : Sarma (2012)

Seperti yang telah dijelaskan sebelumnya, nilai indeks dari setiap dimensi terletak antara 0 dan $\mathbf{W}_{\mathrm{i}}$. Nilai $\mathrm{d}_{\mathrm{i}}$ yang lebih tinggi mengindikasikan lebih banyak titik ideal pada dimensi ke i. Titik $X$ $=\left(d_{1}, d_{2}, d_{3}\right)$ menunjukkan pencapaian inklusi keuangan pada sebuah provinsi. Kemudian pada ruang dimensi, point $\mathbf{O}=$ $(0,0,0)$ merepresentasikan situasi yang terburuk, sedangkan titik $W=\left(w_{1}, w_{2}, w_{3}\right)-$ di mana $W_{1}, w_{2}$, dan $w_{3}$ adalah bobot setiap dimensi - yang mewakili situasi paling ideal untuk seluruh dimensi (Sarma, 2012).

Dengan titik $W=(1,1,1)$, maka rumus akhir dari IFI adalah sebagai berikut:

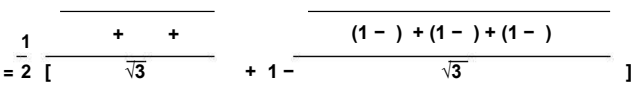

Rumus IFI didapatkan dengan menghitung rata-rata nilai $X 1$ dan $X 2$ yang merepresentasikan posisi antara titik paling buruk dan titik ideal.

Hasil pengukuran IFI dibagi menjadi tiga kategori: (i) IFI rendah jika nilai IFI kurang dari 0,3; (ii) IFI medium jika nilai IFI berada di antara 0,3 dan 0,6 , dan (iii) IFI tinggi jika nilai IFI antara 0,6 dan 1 (Sarma, 2012).

2. Untuk menjawab pertanyaan kedua penelitian, peneliti menggunakan metode analisis Korelasi Pearson berupa Product Moment Coefficient of Correlation, mengingat data variabel model yang digunakan berbentuk rasio. Metode ini mengadopsi penelitian yang dilakukan oleh Gupta et. al.

(2014), dengan formula:

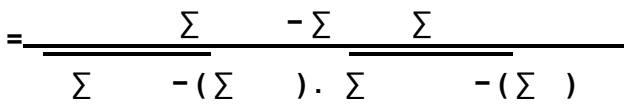

dimana :

$r \quad: \quad$ nilai korelasi pearson

$X \quad$ : average variabel Indeks Inklusi Keuangan Syariah (IFIS)

Y : average variabel Human Development Index (HDI)

n : jumlahsampel

Selain itu, untuk memperkuat hasil analisis hubungan antara inklusifitas keuangan dan indeks pembangunan manusia, penelitian ini juga menggunakan scatter plot untuk melihat hubungan tersebut secara grafis.

\subsection{Kerangka Pemikiran}

Pengukuran inklusifitas (inclusiveness) pada sektor keuangan syariah dalam penelitian ini menggunakan perhitungan Index of Financial Inclusion (IFI) pada perbandingan $\mathbf{3 4}$ provinsi yang ada di Indonesia.

Dalam indeks yang disajikan dalam penelitian ini, IFI dibangun dengan menggunakan dimensi aksesibilitas, availibilitas jasa perbankan, dan penggunaan sistem perbankan. Dikarenakan sektor keuangan menjadi hal utama dalam sistem ekonomi Indonesia, sistem keuangan sering digunakan sebagai pintu masuk

keberlanjutan pertumbuhan ekonomi (sustainable economic growth). Dengan 
melakukan pengukuran pada IFI pada database provinsi di Indonesia, maka data tersebut dapat membantu pengambil kebijakan untuk memprioritaskan reformasi dengan baik untuk mendorong desain kebijakan dengan lebih kuat berdasarkan temuan empiris sehingga pada gilirannya akan meningkatkan kesejahteraan masyarakat sebegai salah satu tujuan bernegara (Lihat Gambar )

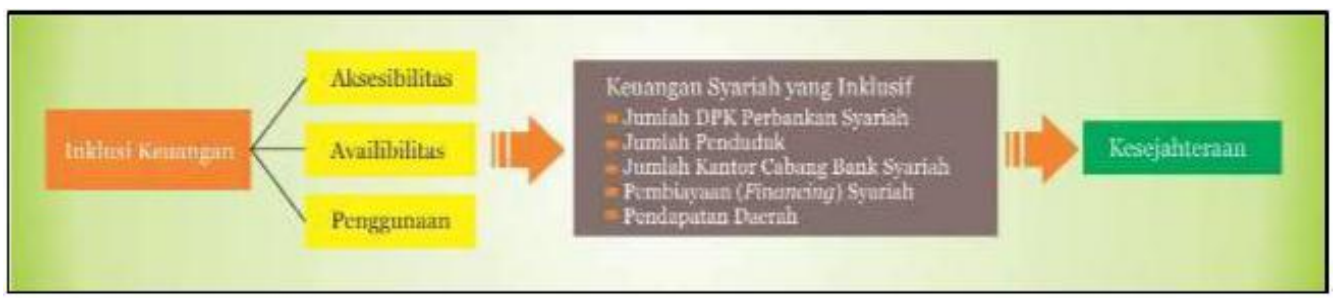

Gambar 2. Kerangka Pemikiran

\section{HASIL DAN ANALISIS}

4.1. Inklusi Keuangan Syariah

Terdapat program transisi untuk memberdayakan masyarakat miskin dengan menggunakan kredit mikro untuk pembiayaan mikro. Pada prosesnya, inklusifitas keuangan menawarkan sejumlah jasa keuangan yang lebih luas termasuk kredit, simpanan, transfer uang, dan asuransi (Robinson, 2001, Armendariz dan Murdoch, 2010). Dengan tujuan pemberdayaan masyarakat untuk kehidupan yang lebih baik, konsep inklusi keuangan menjadi sangat penting untuk diimplementasikan.
Inklusi keuangan harus didukung dengan analisis empiris tentang bagaimana mengukur inklusi keuangan pada indikator ekonomi agregat. Lebih jauh lagi, hal ini dapat meningkatkan partisipasi masyarakat miskin pada pertumbuhan ekonomi dan akhirnya menciptakan pertumbuhan yang inklusif. Untuk menerapkannya, maka database Indonesia tentang inklusi keuangan dapat membantu mengembangkan kapasitas statistik lokal. Di samping itu, perbandingan antara indikator inklusi keuangan dan ditingkatkan antar ekonomi dan antarwaktu.

Tabel 2

Statistik Deskriptif Dimensi Inklusi Keuangan (D)

\begin{tabular}{|c|c|c|c|c|c|c|c|}
\hline \multicolumn{8}{|c|}{ Dimensi Aksesibilitas ( $\left.D_{1}\right)$} \\
\hline Stat. & 2010 & 2011 & 2012 & 2013 & 2014 & 2015 & Average \\
\hline Min & 0.01 & 0.03 & 0.03 & 0.03 & 0.03 & 0.02 & 0.03 \\
\hline $\operatorname{Max}$ & 131.26 & 151.04 & 195.11 & 248.43 & 269.19 & 273.65 & 211.45 \\
\hline Ave. & 8.36 & 10.29 & 14.23 & 17.74 & 18.98 & 19.29 & 14.82 \\
\hline Stdev. & 22.75 & 26.34 & 34.24 & 43.13 & 46.66 & 47.46 & 36.76 \\
\hline \multicolumn{8}{|c|}{ Dimensi Availabilitas $\left(\mathrm{D}_{2}\right)$} \\
\hline Stat. & 2010 & 2011 & 2012 & 2013 & 2014 & 2015 & Average \\
\hline Min & - & - & - & - & - & - & $\cdot$ \\
\hline Max & 0.29 & 0.32 & 0.31 & 0.31 & 0.31 & 0.30 & 0.31 \\
\hline Ave. & 0.05 & 0.05 & 0.06 & 0.06 & 0.06 & 0.05 & 0.06 \\
\hline Stdev. & 0.07 & 0.07 & 0.07 & 0.07 & 0.07 & 0.06 & 0.07 \\
\hline \multicolumn{8}{|c|}{ Dimensi Penggunaan $\left(D_{3}\right)$} \\
\hline Stat. & 2010 & 2011 & 2012 & 2013 & 2014 & 2015 & Average \\
\hline Min & 1.519379 & 2.52716 & 2.952273 & 3.773752 & 3.186194 & 2.551185 & 2.75 \\
\hline Max & 3341.919 & 4129.473 & 4748.192 & 5024.911 & 5117.371 & 5452.086 & 4635.66 \\
\hline Ave. & 360.4269 & 414.8972 & 615.2478 & 641.5791 & 579.093 & 660.0283 & 545.21 \\
\hline Stdev. & 657.326 & 827.1698 & 1058.599 & 1067.032 & 996.0246 & 1144.744 & 958.48 \\
\hline
\end{tabular}


Tabel 2 menunjukkan statistik deskriptif tiga dimensi pengukuran inklusi keuangan pada 33 provinsi di Indonesia yang telah diestimasi pada tahun 2010-2015. Hasilnya menunjukkan beberapa indikator seperti: minimum (Min), maksimum (Max), rata-rata (Ave.), dan standar deviasi.

Sebuah sistem keuangan yang inklusif harus memiliki pengguna sebanyak mungkin, oleh karena itu sistem keuangan yang inklusif harus menjangkau secara luas di antara pengguna. Proporsi dari populasi yang memiliki rekening bank merupakan sebuah ukuran untuk penetrasi perbankan. Salah satu variabel yang dapat mencerminkan ukuran ini adalah jumlah DPK di rata 211 juta rupiah per 1000 penduduk (Lihat Grafik 1 pada Lampiran 1).

Selain penetrasi perbankan, ukuran lain dalam sistem keuangan yang inklusif adalah ketersediaan jasa perbankan. Ukuran ini menggambarkan jangkauan jasa perbankan sehingga masyarakat dapat mengakses jasa keuangan di mana pun berada. Indikator dari ketersediaan jasa perbankan adalah jumlah outlet (baik itu kantor, kantor cabang, ATM, dan sebagainya). Dalam penelitian ini, ketersediaan jasa perbankan diukur dengan jumlah kantor layanan bank syariah meliputi Bank Pembiayaan Rakyat Syariah per $\mathbf{1 0 0 . 0 0 0}$ penduduk. Pada tahun 2010-2015, rata-rata jumlah perbankan

Tabel 3

Statistik Deskriptif Indeks Inklusi Keuangan Syariah (d)

\begin{tabular}{|c|c|c|c|c|c|c|}
\hline \multicolumn{7}{|c|}{ Indeks Aksesibilitas ( $\left.d_{1}\right)$} \\
\hline Stat. & 2010 & 2011 & 2012 & 2013 & 2014 & 2015 \\
\hline Min & 0.000 & 0.000 & 0.000 & 0.000 & 0.000 & 0.000 \\
\hline Max & 1.0000 & 1.0000 & 1.0000 & 1.0000 & 1.0000 & 1.0000 \\
\hline Ave & 0.0636 & 0.0680 & 0.0728 & 0.0713 & 0.0704 & 0.0704 \\
\hline Stdev. & 0.1734 & 0.1744 & 0.1755 & 0.1736 & 0.1734 & 0.1735 \\
\hline \multicolumn{7}{|c|}{ Indeks Availabilitas ( $\left.d_{2}\right)$} \\
\hline Stat. & 2010 & 2011 & 2012 & 2013 & 2014 & 2015 \\
\hline Min & 0.000 & 0.000 & 0.000 & 0.000 & 0.000 & 0.000 \\
\hline Max & 1.0000 & 1.0000 & 1.0000 & 1.0000 & 1.0000 & 1.0000 \\
\hline Ave & 0.1813 & 0.1666 & 0.1794 & 0.1861 & 0.1855 & 0.1781 \\
\hline Stdev. & 0.2284 & 0.2152 & 0.2180 & 0.2167 & 0.2157 & 0.2125 \\
\hline \multicolumn{7}{|c|}{ Indeks Penggunaan (d 3 ) } \\
\hline Stat. & 2010 & 2011 & 2012 & 2013 & 2014 & 2015 \\
\hline Min & 0.000 & 0.000 & 0.000 & 0.000 & 0.000 & 0.000 \\
\hline Max & 1.0000 & 1.0000 & 1.0000 & 1.0000 & 1.0000 & 1.0000 \\
\hline Ave & 0.1074 & 0.0999 & 0.1290 & 0.1270 & 0.1126 & 0.1206 \\
\hline Stdev. & 0.1968 & 0.2004 & 0.2231 & 0.2125 & 0.1948 & 0.2101 \\
\hline
\end{tabular}

\section{Sumber : Hasil Olah Data}

bank per 1000 penduduk dewasa. Penelitian ini menggunakan rasio nilai DPK pada perbankan syariah yang terdiri dari Bank Umum Syariah, Unit Usaha dan Bank Pembiayaan Rakyat Syariah terhadap 1000 penduduk. Pada tahun 2010-2015, rata-rata total jumlah DPK perbankan syariah per 1000 penduduk secara total di Indonesia adalah sekitar 14,82 juta rupiah (Lihat Tabel 2). Dari 33 provinsi yang ada, Provinsi Kepulauan Bangka Belitung memiliki rata-rata jumlah DPK pada perbankan syariah tertinggi dibanding provinsi lainnya yaitu mencapai rata- syariah untuk melayani setiap 100.000 penduduk di Indonesia adalah sebesar 0,05 unit atau dengan kata lain tersedia 5 unit untuk melayani 10 juta penduduk (Lihat Tabel 2). Jumlah ini tentu saja merupakan jumlah yang sangat minim terkait dengan ketersediaan layanan perbankan syariah di daerah. Dari 33 provinsi yang ada, Provinsi Daerah Istimewa Yogyakarta menempati posisi teratas tingkat ketersediaan layanan perbankan syariah dibanding provinsi lainnya yaitu mencapai ratarata 0,30 unit per 100.000 penduduk atau 3 unit 
per 1 juta penduduk (Lihat Grafik 2 pada Lampiran 2).

Selanjutnya, memiliki rekening di bank tidaklah cukup untuk menunjukkan sistem keuangan yang inklusif. Keberadaan jasa keuangan pun harus memiliki cukup manfaat bagi masyarakat. Manfaat bagi masyarakat dapat dalam berbagai bentuk, di antaranya berupa kredit, deposito, pembayaran, remitansi, transfer, dan lain-lain. Oleh karena itu, indikator penggunaan ini harus dimasukkan ke dalam pengukuran sistem keuangan yang inklusif. Dalam penelitian ini, indikator penggunaan dilihat dari proporsi jumlah pembiayaan (financing) syariah oleh perbankan syariah yang terdiri dari Bank Umum Syariah, Unit Usaha dan Bank Pembiayaan Rakyat Syariah terhadap nilai PDRB pada tiap provinsi selama Tahun 20102015. Hasil estimasi menemukan bahwa ratarata penggunaan pembiayaan perbankan syariah pada periode penelitian di Indonesia adalah sebesar 545 miliar rupiah (Lihat Tabel 2). Tidak jauh berbeda dengan dimensi aksesibilitas, Provinsi Kepulauan Bangka Belitung juga menempati posisi tertinggi dalam penggunaan jasa perbankan syariah oleh masyarakat (Lihat Grafik 3 pada Lampiran 3).

Dari proporsi Indeks Inklusi Keuangan tiga dimensi pada Tabel 3 di atas, dimensi availabilitas memiliki nilai rata-rata (average) yang paling tinggi selama periode tahun 20102015, diikuti oleh penggunaan kemudian aksesibilitas. Hasil ini mengindikasikan bahwa inklusi keuangan syariah di Indonesia utamanya ditentukan oleh dimensi availabilitas dan pengunaan. Sementara dimensi availabilitas hanya memiliki proporsi yang relatif kecil dibanding keduanya. Selain availibilitas, dimensi penggunanaan juga menunjukkan nilai indeks yang relatif baik. Hal ini menunjukkan bahwa perbankan syariah telah memberikan peran intermediasinya kepada masyarakat melalui pembiayaan syariah di berbagai bidang, sektor dan penggunaan.

Pada banyak provinsi, proporsi jumlah penduduk memiliki potensi untuk mencapai aksesibilitas yang tinggi pada sistem keuangan syariah dengan tersedianya berbagai kantor layanan syariah (availabilitas), namun mereka tidak menggunakan layanan yang ada dengan baik dikarenakan adanya kendala berupa kantor cabang yang tidak dapat dijangkau dikarenakan tempat tinggal yang begitu terpencil serta kendala fisik dan psikologis. Beberapa literatur telah mengungkapkan bahwa jasa-jasa tersebut tidak digunakan dengan baik, walaupun masyarakat memiliki akses terhadap jasa keuangan (Sarma, 2012). Akibatnya, tingkat rata-rata indeks inklusi keuangan syariah dari dimensi aksesibilitas yang diukur dari rasio

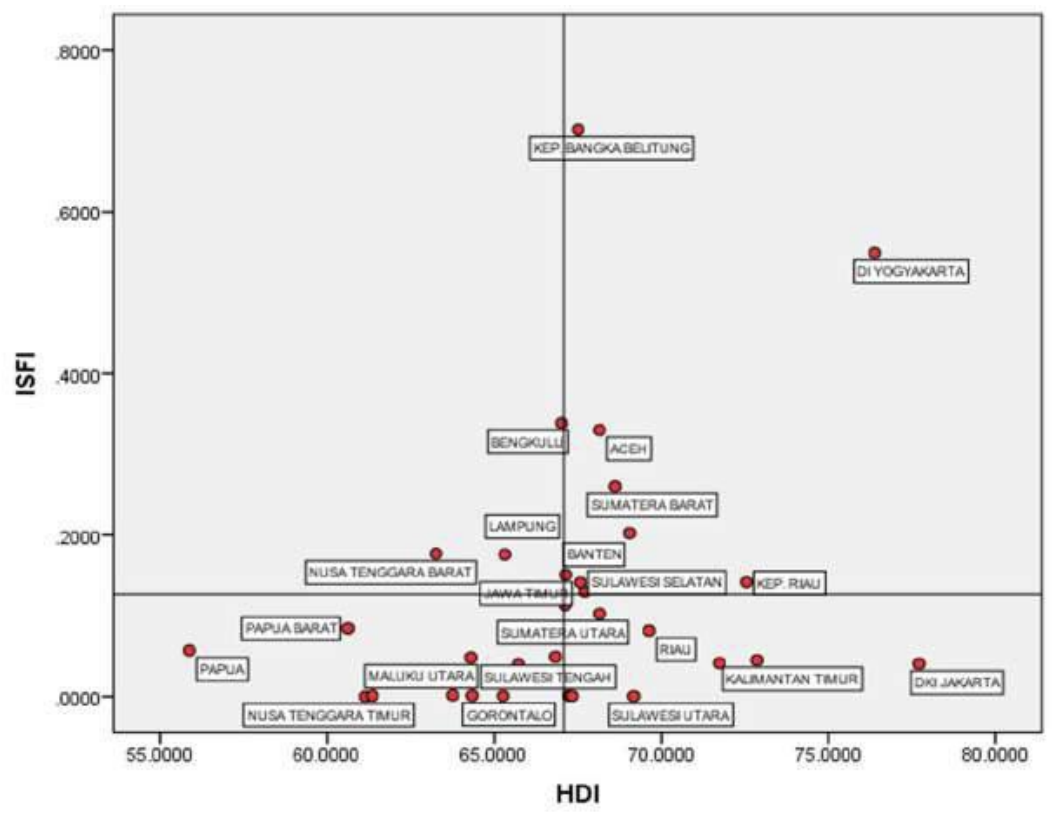

Sumber : Hasil Olah Data

Grafik 7. Scatter Plot nilai ISFI dan HDI pada 33 Provinsi di Indonesia 
jumlah DPK perbankan baik pada Bank Umum Syariah, Unit Usaha maupun Bank Pembiayaan Rakyat Syariah per 1.000 penduduk miskin dewasa relatif rendah.

Dalam statistik perbankan syariah di Indonesia, kita dapat menemukan bahwa meskipun kantor layanan bank syariah di $\mathbf{3 3}$ provinsi di Indonesia telah berdiri dan beroperasi (Lihat Grafik 4 pada Lampiran 4), tetapi jumlah DPK yang mencerminkan kepemilikan rekening baik tabungan maupun deposito masyarakat pada perbankan syariah masih belum merata di seluruh Indonesia. Grafik 5 (Lampiran 5) menunjukkan bahwa pada banyak provinsi di Kawasan Timur Indonesia, penggunaan jasa perbankan syariah dari nilai DPK masih relatif jauh lebih rendah daripada provinsi yang berada pada Kawasan Barat Indonesia.

Seperti yang diindikasikan oleh nilai dimensi aksesibilitas yang rendah, availibilitas yang tinggi cenderung tidak dimanfaatkan secara optimal oleh masyarakat untuk menggunakan jasa keuangan formal sebagai sumber utama pembiayaan. Daripada menggunakan fasilitas perbankan formal, masyarakat cenderung menggunakan jasa keuangan informal. Peran yang dominan institusi keuangan non-formal di Indonesia, khususnya pada daerah terpencil, mengindikasikan bahwa pasar keuangan syariah di Indonesia tidak berfungsi dengan baik.

Selanjutnya, pada analisis ISFI Syariah pada 33 provinsi di Indonesia, hasilnya menunjukkan bahwa Provinsi Kep. Bangka Belitung dikategorikan sebagai provinsi dengan IFI yang tinggi (hijau) dengan nilai average ISFI selama periode 2010-2015 sebesar 0,702. Bahkan pada tahun 2010, provinsi ini mencatat nilia ISFI yang sangat tinggi yaitu sebesar 0,726. Provinsi dengan nilai IFI medium (kuning) adalah Daerah Istimewa Yogyakarta, Bengkulu dan Aceh. Sedangkan provinsi-provinsi lainnya tergolong pada tingkat IFI rendah (cokelat) diantaranya adalah Nusa Tenggara Timur, Sulawesi Utara, Sulawesi Tenggara, Sulawesi Tengah, Gorontalo, Jambi, Sulawesi Barat, Kalimantan Barat, Sumatera Selatan, Papua, Papua Barat, Maluku, Maluku Utara, dan lainnya (Lihat Tabel 4 pada Lampiran 7).

Sebagaimana ditunjukkan oleh total ratarata ISFI di Indonesia yaitu sebesar 0,127 ,
Indonesia masuk dalam kategori ISFI rendah selama periode penelitian. Seperti yang ditunjukkan pada Tabel 4 (Lampiran 7), sebagian besar provinsi di Indonesia masuk dalam kategori ISFI rendah. Beberapa provinsi yang memiliki nilai ISFI rendah yang relatif konsisten pada tahun 2010-2015 adalah umumnya provinsi di Pulau Sulawesi, Kalimantan, Maluku, Nusa Tenggara, Papua dan sebagian Sumatera. Saat banyak pihak sepakat tentang kebijakan dasar yang penting bagi inkulisifitas dan penurunan kemiskinan, beberapa literatur baru telah mengidentifikasi hubungan antara inklusi keuangan dan pembangunan (Sarma, 2008). Beberapa determinan utama pembangunan yang digunakan dalam literaturliteratur tersebut berhubungan dengan perbaikan sektor keuangan. Lebih lanjut, meskipun hanya satu provinsi dengan ISFI yang tinggi, tetapi Indonesia secara umum menunjukkan kinerja yang baik dan optimis dalam hal inklusifitas sektor keuangan syariah selama periode tersebut. Terdapat level transisi pada sebagian besar provinsi di Indonesia dari ISFI yang rendah ke ISFI yang tinggi (Lihat Grafik 6 pada Lampiran 6).

\subsection{Inklusi Keuangan dan Kesejahteraan Dalam} mengukur hubungan antara indeks

inklusi keuangan dan kesejahteaan masyarakat yang diukur dari nilai Human Development Index, penelitian ini mengestimasi hubungan tersebut dengan pearson correlation.

Hasil estimasi menunjukkan bahwa para periode 2010-2015, average inklusi keuangan syariah pada 33 provinsi di Indonesia berkorelasi positif dan signifikan terhadap indeks pembangunan manusia. Nilai koefisien korelasi sebesar 0.288 dengan signifikansi 0.052 (lebih kecil dari alpha 0.1) menunjukkan adanya hubungan yang nyata di antara keduanya. Artinya, ketika inklusi keungan syariah naik, maka kesejahteraan masyarakat juga cenderung akan meningkat. Dengan kata lain, daerah yang memiliki indeks keuangan inklusif yang tinggi, cenderung memiliki tingkat kesejahteraan yang tinggi pula (Lihat Tabel 5 pada Lampiran 8).

Berdasarkan scatter plot di atas, penelitian ini mematok titik pada nilai ISFI dan HDI pada masing-masing 33 provinsi tersebut. Umumnya, provinsi dengan HDI yang tinggi dan medium dapat dianalogikan relatif memiliki inklusi 
keuangan yang tinggi pula. Provinsi Kep. Bangka Belitung, DI Yogyakarta, Bengkulu dan Aceh yang memiliki nilai ISFI yang tinggi juga memiliki nilai HDI di atas rata-rata. Sama halnya dengan provinsi yang memiliki ISFI yang rendah juga memiliki HDI yang relatif rendah di bawah rata-rata seperti Papua, Papua Barat, Nusa Tenggara Timur, Maluku Utara dan lainnya.

\section{KESIMPULAN}

Hasil pada penelitian ini menunjukkan bahwa Indonesia masuk dalam kategori ISFI rendah selama periode penelitian. Secara umum, inklusi keuangan syariah di Indonesia utamanya ditentukan oleh dimensi availabilitas dan pengunaan. Sementara dimensi availabilitas hanya memiliki proporsi yang relatif kecil dibanding keduanya. Temuan ini bermakna bahwa kelompok masyarakat tidak sepenuhnya menggunakan jasa keuangan formal, khususnya, sebagai sumber keuangan dan pembiayaan utama. Sehingga, pengambil kebijakan perlu untuk meningkatkan availabilitas keuangan syariah dengan menambah dan memperluas layanan perbankan syariah di Indonesai khususnya pada kawasan timur Indonesia. Selain itu, dari hasil analisis kuantitatif, penelitian ini juga menemukan bahwa Index of Syariah Financial Inclusion (ISFI) dan Human Development Index (HDI) memiliki hubungan yang positif dan signifikan satu sama lain. Umumnya, provinsi dengan HDI yang tinggi dan medium dapat dianalogikan relatif memiliki inklusi keuangan yang tinggi pula. Sama halnya dengan provinsi yang memiliki IFI yang rendah juga memiliki HDI yang relatif rendah seperti Papua, Papua Barat, Nusa Tenggara Timur, Maluku Utara dan lainnya.

Dalam mengukur inklusifitas keuangan syariah pada dimensi pengukuran availibilitas, penelitian ini hanya menggunakan data jumlah Bank Pembiayaan Syariah pada 33 provinsi di Indonesia mengingat keterbatasan data yang dapat diperoleh. Pada penelitian berikutnya, disarankan untuk menggunakan data perbankan yang lebih lengkap yang meliputi Bank Umum Syariah dan Unit Usaha Syariah serta lingkup keuangan syaraiah yang dilebih luas diluar perbankan seperti obligasi syariah, saham syariah dan lainnya. Penelitian berikutnya juga disarankan untuk memperhitungkan indikator pengukuran atau parameter lainnya seperti affordability, timeliness dan quality of banking services serta new technological advances in banking sector seperti mobile banking dan internet banking. Selain itu, penelitian ini juga belum mengukur determinan pembentukan indeks inklusi keuangan syariah di Indonesia sehingga penting untuk menjadi agenda penelitian berikutnya.

\section{DAFTAR PUSTAKA}

Allen et al. 2012. The Foundations of Financial Inclusion: Understanding Ownership and Use of Formal Accounts. Policy Research Working paper 6290, Development Research Group, Finance and Private Sector Development Team, World Bank.

Armendariz, B. and J. Morduch. (2010). The Economics of Microfinance. 2nd Edition. London: The MIT Press.

Asian Development Bank (ADB). (2011). Key Indicators for Asia and the Pasific 2011: Framework for Inclusive Growth Indicators, Special Supplement. Manila: ADB.

Bank Indonesia. (2014). Booklet Financial Inclusion. Jakarta: Bank Indonesia

Beck et al. (2007). Finance, Inequality and the Poor. Journal of Economic Growth. 12, 27-49.

Demirgüç-Kunt, A. and L. Klapper. (2012). Measuring Financial Inclusion: The Global Findex Database. Policy Research Working Paper, 6025.

Demirgüç-Kunt, A., T. Beck and P. Honohan. (2008). Finance for All? Policies and Pitfalls in Expanding Access. Washington D.C.: A World Bank Policy Research Report.

Gupta, Anurag, et al. (2014). Financial Inclusion and Human Development: A State-Wise Analysis From India. International Journal of Economics, Commerce and Management, United Kingdom Vol. II, Issue 5, 2014

Honohan, P. (2008) Cross-Country Variation in Household Access to Financial Services. Journal of Banking and Finance 32: 2493-2500

Leyshon, A., \& Thrift, N. (1995). Geographies of

Financial Exclusion: Financial Abandonment in Britain and the United States. JSTOR, New Series, Vol. 20, No. 3 , 312-241.

Rangarajan Committee. (2008). Report of the 
Committee on Financial Inclusion.

Government of India.

Reyes, G. P. (2010). Financial Inclusion Indicators for Developing Countries: The Peruvian Case. Peru: Superintendency of Banking.

Robinson, M.S. (2001). The Microfinance

Revolution: Sustainable Finance for the Poor. Washington: The World Bank.

Sanjaya, I Made dan Nursechafia. (2016). Inklusi Keuangan dan Pertumbuhan Inklusif: Analisis Antar Provinsi di Indonesia. Buletin Ekonomi Moneter dan Perbankan, Volume 18, Nomor 3, Januari 2016

Sarma, M. (2008). Index of Financial Inclusion. ICRIER Working Paper, 215.

Sarma, M., and J. Pais. (2008). Financial Inclusion and Development: A Cross Country Analysis. Paper Presented at the Conference on Equality, Inclusion and Human Development organized by HDCA and IHD, New Delhi.

Sarma, M. (2012). Index of Financial Inclusion A measure of financial sector inclusiveness. Berlin Working Papers on Money, Finance, Trade and Development, No.7, p.1-34.

Ummah, Bintan Badriatul. (2013). Analisis Keterkaitan Inklusi Keuangan dengan Pembangunan di Asia. Skripsi : Departemen IImu Ekonomi Fakultas Ekonomi dan Manajemen Institut Pertanian Bogor

Van der Werff et al. (2012). A Cross-country analysis of financial inclusion within the OECD. Consumer Interest Annual Volume 59. 


\section{Lampiran 1}

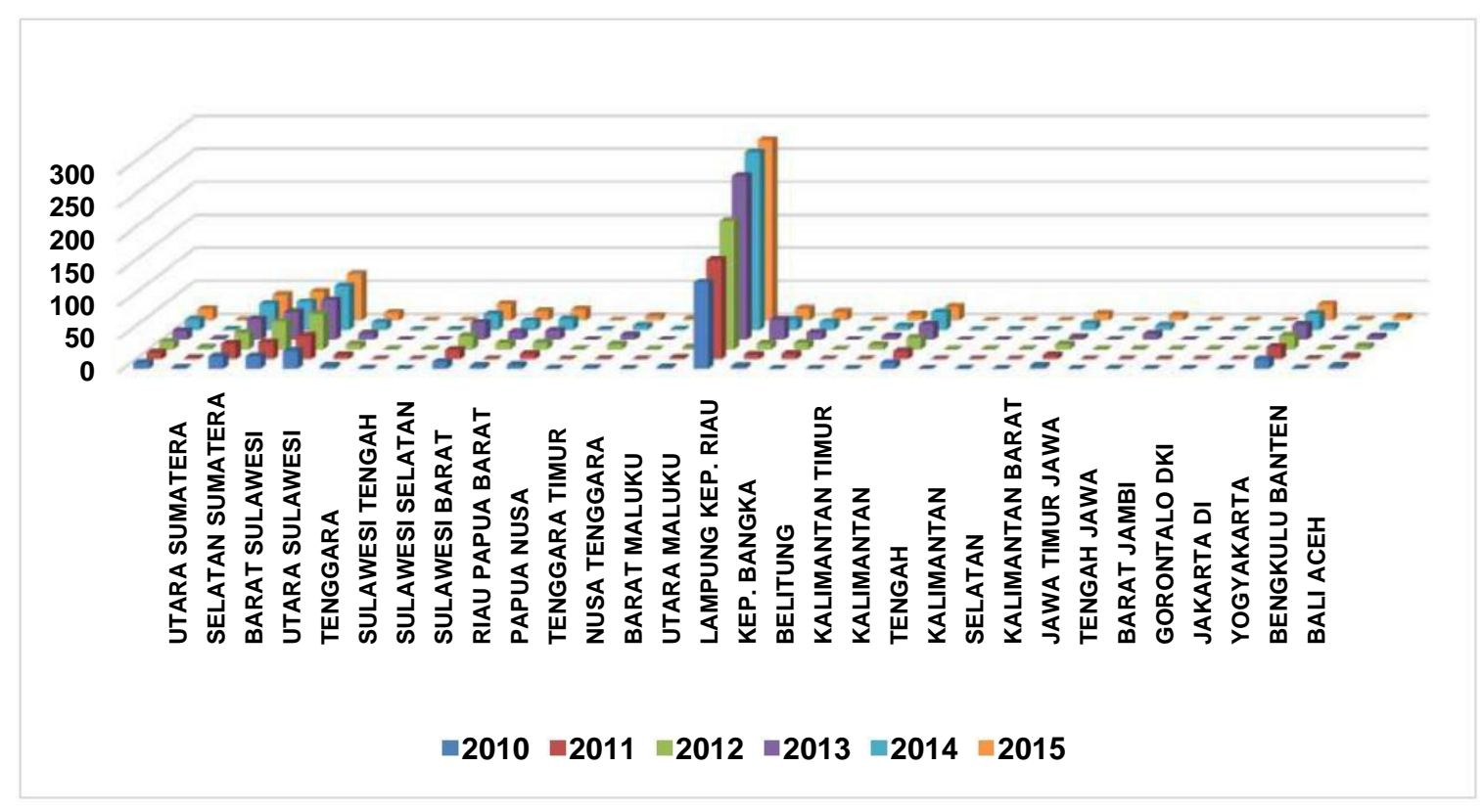

Sumber : Hasil Olah Data

Grafik 1. Dimensi Aksesibilitas $\left(D_{1}\right)$ pada 33 Provinsi di Indonesia

\section{Lampiran 2}

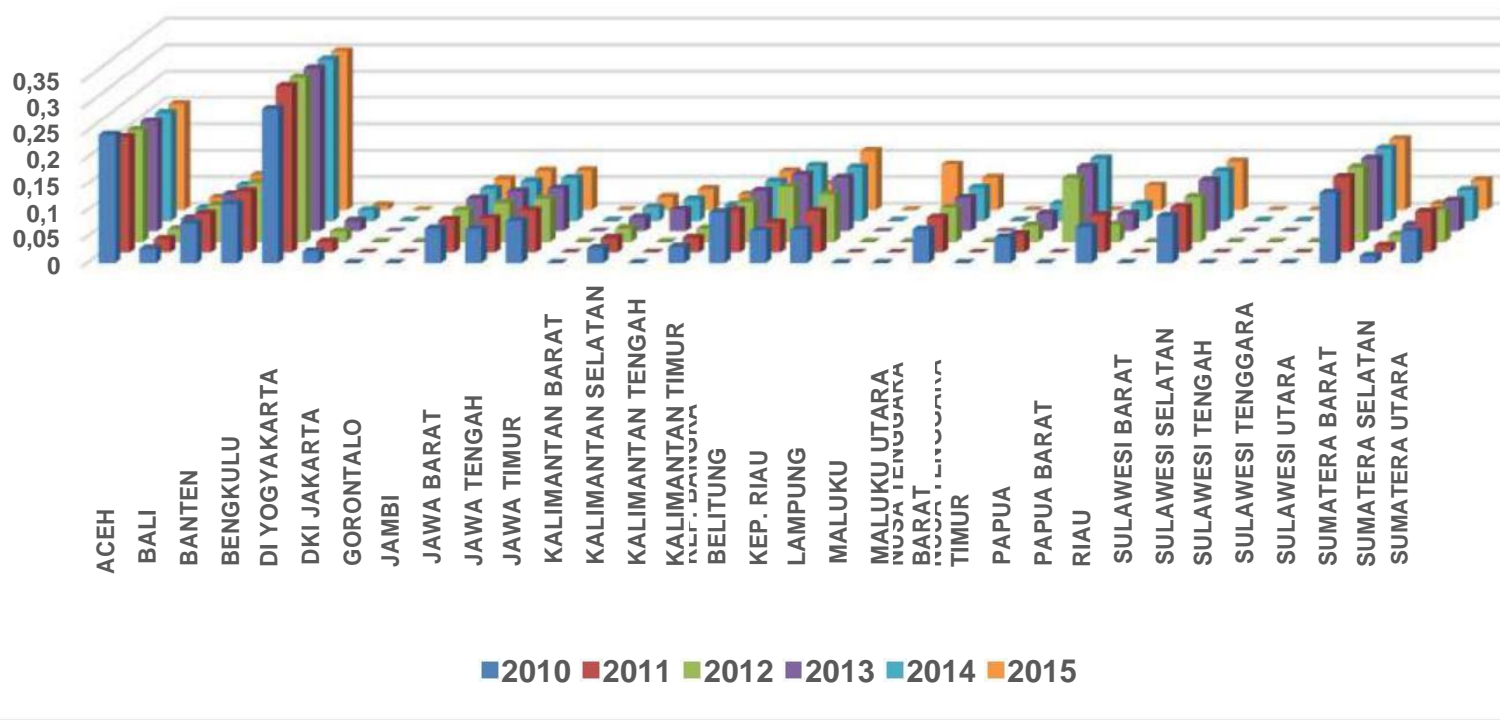

\section{Sumber : Hasil Olah Data}

Grafik 2. Dimensi Availabilitas $\left(D_{2}\right)$ pada 33 Provinsi di Indonesia 


\section{Lampiran 3}

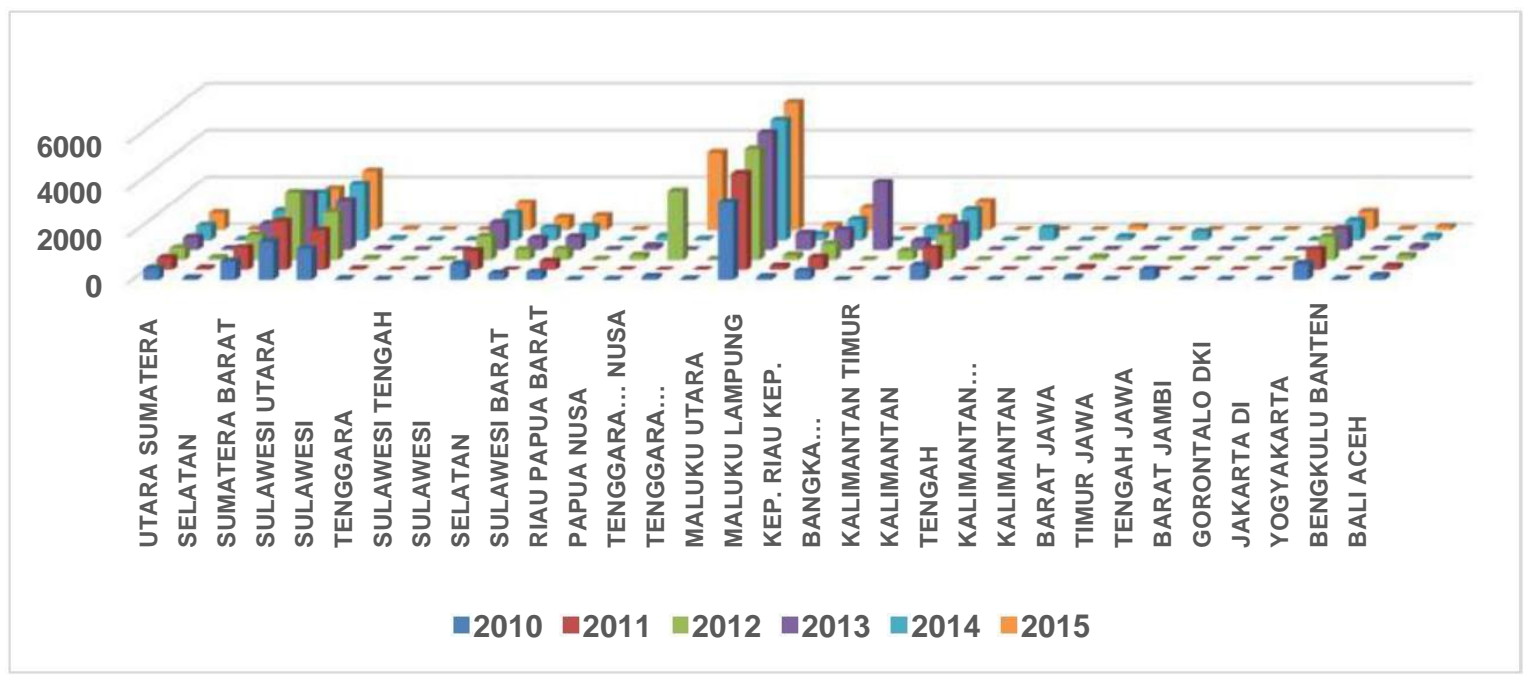

Sumber : Hasil Olah Data

Grafik 3. Dimensi Penggunaan ( $\mathrm{D}_{3}$ ) pada 33 Provinsi di Indonesia

\section{Lampiran 4}

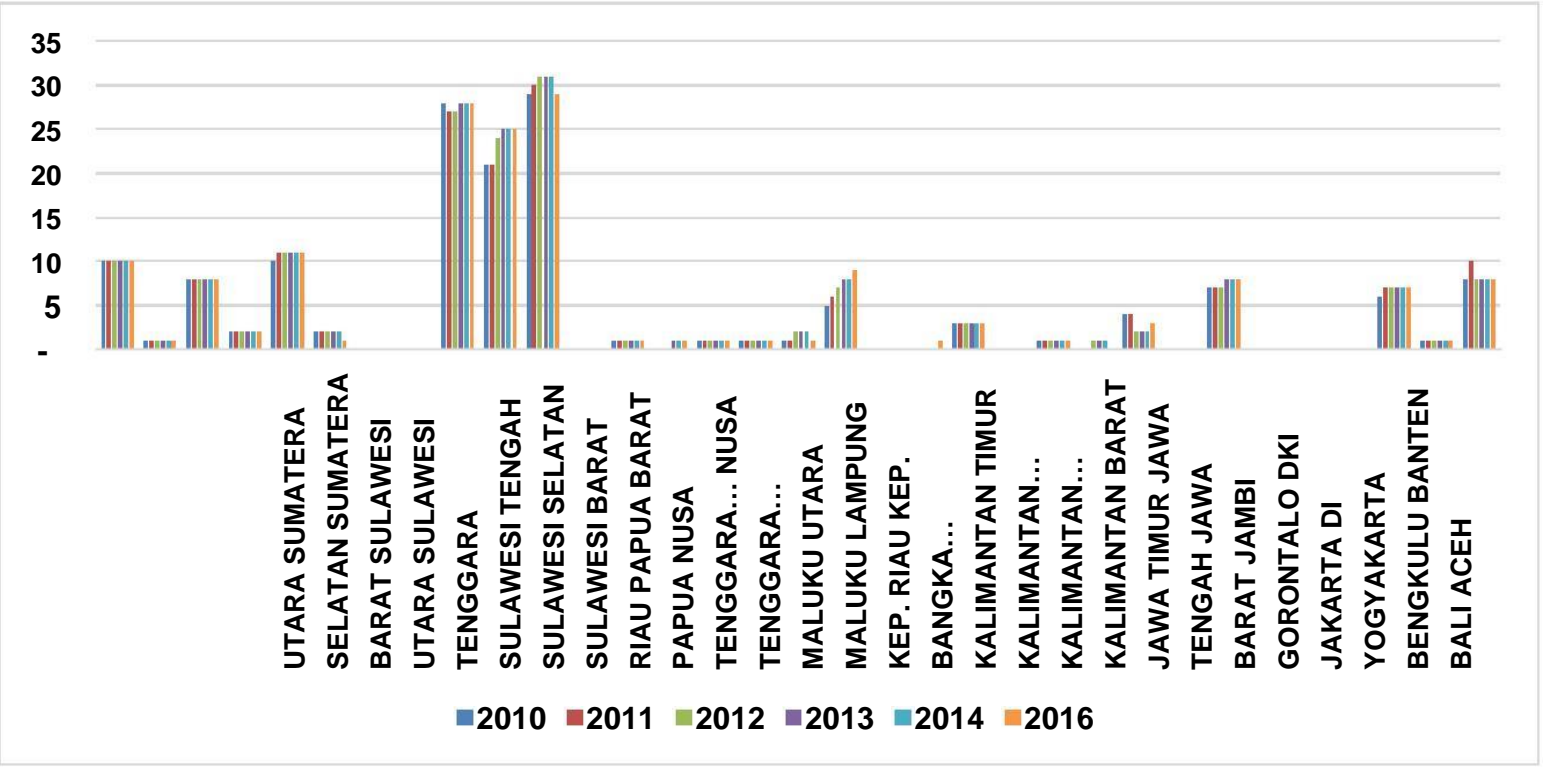

Sumber : Bank Indonesia

Grafik 4. Perkembangan Jumlah Bank Pembiayaan Syariah di Indonesia 


\section{Lampiran 5}

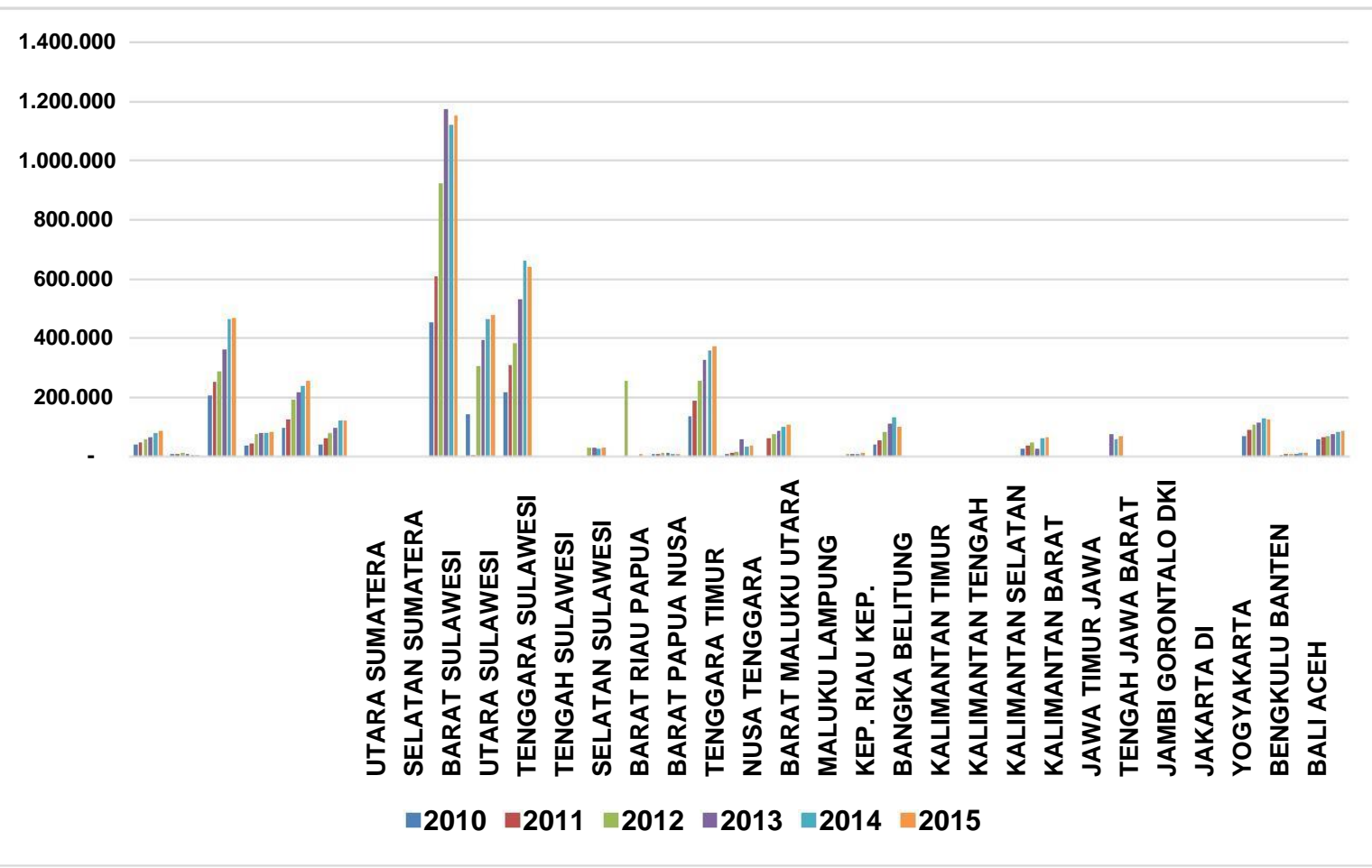

Sumber : Bank Indonesia

Grafik 5. Jumlah DPK Perbankan Syariah

\section{Lampiran 6}

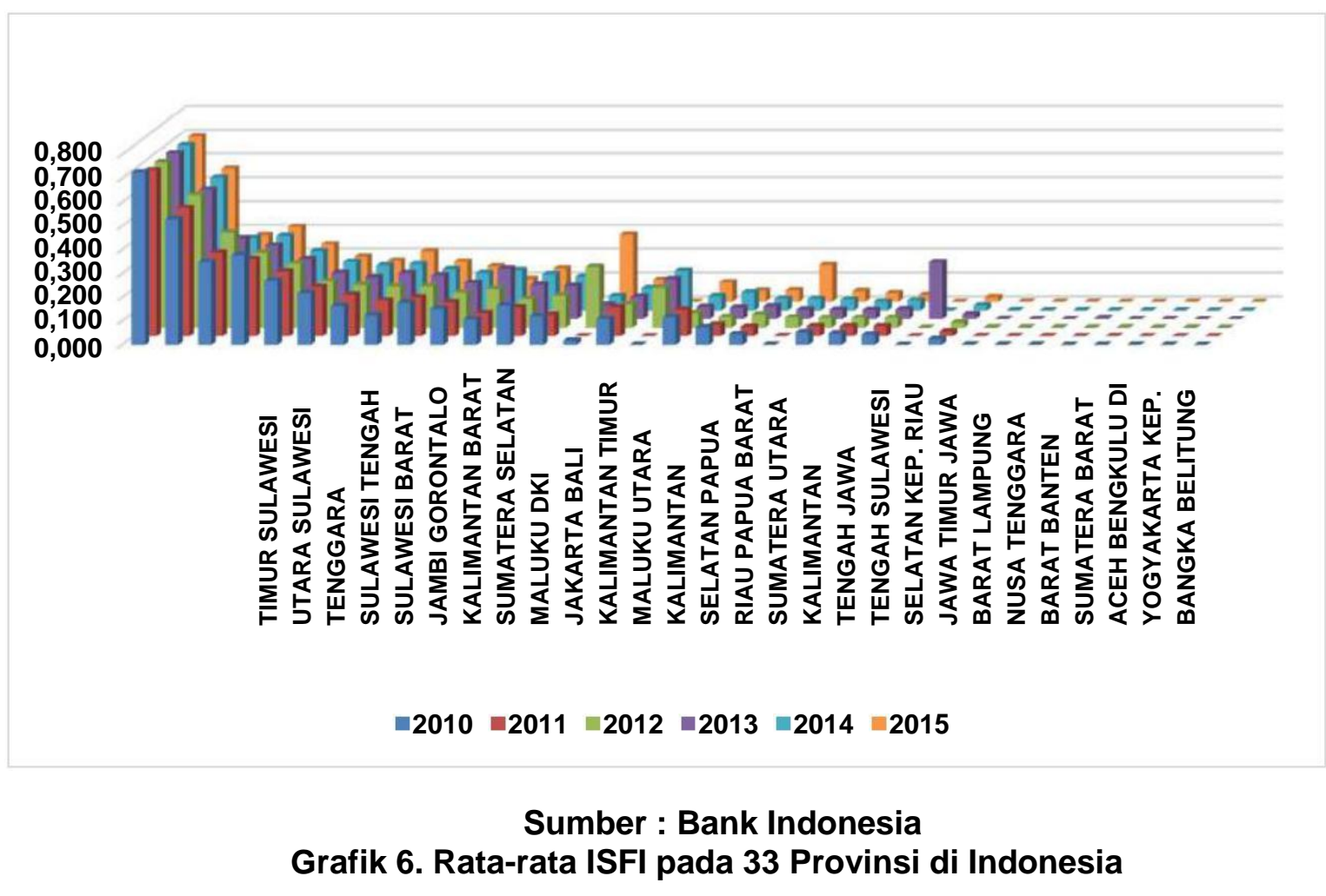




\section{Lampiran 7}

Tabel 4

ISFI pada 33 Provinsi di Indonesia

\begin{tabular}{|c|c|c|c|c|c|c|c|}
\hline Provinsi & 2010 & 2011 & 2012 & 2013 & 2014 & 2015 & Average \\
\hline KEP. BANGKA BELITUNG & 0.726 & 0.699 & 0.697 & 0.697 & 0.697 & 0.696 & 0.702 \\
\hline DI YOGYAKARTA & 0.529 & 0.541 & 0.559 & 0.546 & 0.559 & 0.562 & 0.549 \\
\hline BENGKULU & 0.349 & 0.353 & 0.400 & 0.341 & 0.306 & 0.281 & 0.339 \\
\hline ACEH & 0.379 & 0.325 & 0.315 & 0.310 & 0.315 & 0.317 & 0.327 \\
\hline SUMATERA BARAT & 0.271 & 0.273 & 0.269 & 0.254 & 0.250 & 0.244 & 0.260 \\
\hline BANTEN & 0.218 & 0.207 & 0.196 & 0.196 & 0.206 & 0.191 & 0.202 \\
\hline NUSA TENGGARA BARAT & 0.163 & 0.176 & 0.180 & 0.177 & 0.190 & 0.174 & 0.177 \\
\hline LAMPUNG & 0.126 & 0.152 & 0.173 & 0.195 & 0.196 & 0.213 & 0.176 \\
\hline JAWA BARAT & 0.177 & 0.165 & 0.174 & 0.185 & 0.174 & 0.170 & 0.174 \\
\hline JAWA TIMUR & 0.152 & 0.143 & 0.148 & 0.154 & 0.158 & 0.150 & 0.151 \\
\hline KEP. RIAU & 0.107 & 0.099 & 0.163 & 0.213 & 0.170 & 0.098 & 0.142 \\
\hline SULAWESI SELATAN & 0.166 & 0.121 & 0.121 & 0.145 & 0.154 & 0.141 & 0.141 \\
\hline JAWA TENGAH & 0.122 & 0.091 & 0.136 & 0.141 & 0.143 & 0.143 & 0.129 \\
\hline KALIMANTAN TENGAH & 0.018 & 0.000 & 0.256 & 0.060 & 0.062 & 0.283 & 0.113 \\
\hline SUMATERA UTARA & 0.110 & 0.122 & 0.099 & 0.095 & 0.095 & 0.094 & 0.103 \\
\hline PAPUA BARAT & 0.000 & 0.000 & 0.168 & 0.169 & 0.167 & 0.000 & 0.084 \\
\hline RIAU & 0.117 & 0.113 & 0.062 & 0.052 & 0.061 & 0.084 & 0.082 \\
\hline PAPUA & 0.075 & 0.049 & 0.046 & 0.048 & 0.077 & 0.048 & 0.057 \\
\hline KALIMANTAN SELATAN & 0.046 & 0.040 & 0.056 & 0.053 & 0.050 & 0.049 & 0.049 \\
\hline MALUKU UTARA & 0.001 & 0.001 & 0.043 & 0.041 & 0.049 & 0.155 & 0.048 \\
\hline KALIMANTAN TIMUR & 0.054 & 0.043 & 0.041 & 0.040 & 0.046 & 0.046 & 0.045 \\
\hline BALI & 0.049 & 0.043 & 0.042 & 0.039 & 0.037 & 0.038 & 0.041 \\
\hline DKI JAKARTA & 0.044 & 0.042 & 0.042 & 0.042 & 0.043 & 0.030 & 0.040 \\
\hline MALUKU & 0.000 & 0.000 & 0.000 & 0.240 & 0.000 & 0.000 & 0.040 \\
\hline SUMATERA SELATAN & 0.024 & 0.022 & 0.021 & 0.021 & 0.021 & 0.021 & 0.022 \\
\hline KALIMANTAN BARAT & 0.001 & 0.001 & 0.002 & 0.002 & 0.002 & 0.002 & 0.002 \\
\hline GORONTALO & 0.002 & 0.001 & 0.001 & 0.001 & 0.001 & 0.001 & 0.001 \\
\hline JAMBI & 0.001 & 0.001 & 0.001 & 0.001 & 0.001 & 0.001 & 0.001 \\
\hline SULAWESI BARAT & 0.000 & 0.000 & 0.001 & 0.005 & 0.000 & 0.000 & 0.001 \\
\hline SULAWESI TENGAH & 0.001 & 0.001 & 0.001 & 0.001 & 0.001 & 0.001 & 0.001 \\
\hline SULAWESI TENGGARA & 0.001 & 0.001 & 0.001 & 0.001 & 0.001 & 0.001 & 0.001 \\
\hline SULAWESI UTARA & 0.000 & 0.000 & 0.001 & 0.000 & 0.000 & 0.000 & 0.000 \\
\hline NUSA TENGGARA TIMUR & 0.000 & 0.000 & 0.000 & 0.000 & 0.000 & 0.000 & 0.000 \\
\hline Average Total & 0.122 & 0.116 & 0.134 & 0.135 & 0.128 & 0.128 & 0.127 \\
\hline
\end{tabular}

\section{Sumber : Hasil Olah Data}




\section{Lampiran 8}

Tabel 5

Hasil Estimasi Korelasi ISFI dan HDI

\begin{tabular}{|c|c|c|c|c|}
\hline \multicolumn{5}{|c|}{ Descriptive Statistics } \\
\hline & Mean & \multirow{2}{*}{\multicolumn{2}{|c|}{$\begin{array}{c}\text { Std. Deviation } \\
.1596270\end{array}$}} & $\mathbf{N}$ \\
\hline ISFI & .127395 & & & 33 \\
\hline HDI & 67.093788 & \multicolumn{2}{|c|}{4.2983207} & 33 \\
\hline \multicolumn{5}{|c|}{ Correlations } \\
\hline & & & ISFI & HDI \\
\hline \multirow[t]{3}{*}{ ISFI } & \multicolumn{2}{|c|}{ Pearson Correlation } & 1 & .288 \\
\hline & \multicolumn{2}{|c|}{ Sig. } & & .052 \\
\hline & \multicolumn{2}{|l|}{$\mathbf{N}$} & 33 & 33 \\
\hline \multirow[t]{3}{*}{ HDI } & \multicolumn{2}{|c|}{ Pearson Correlation } & .288 & 1 \\
\hline & \multicolumn{2}{|c|}{ Sig. } & .052 & \\
\hline & \multicolumn{2}{|l|}{$\mathbf{N}$} & 33 & 33 \\
\hline & Correlation & |nific & 0.11 & \\
\hline
\end{tabular}

